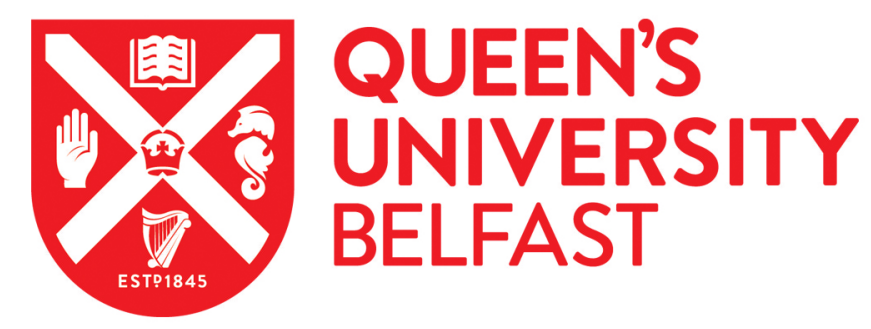

\title{
Soil Cd availability to Indian mustard and environmental risk following EDTA addition to Cd-contaminated soil
}

Jiang, X. J., Luo, Y. M., Zhao, Q. G., Baker, A. G. M., Christie, P., \& Wong, M. H. (2003). Soil Cd availability to Indian mustard and environmental risk following EDTA addition to Cd-contaminated soil. Chemosphere, $50(6)$, 813-818.

Published in:

Chemosphere

Queen's University Belfast - Research Portal:

Link to publication record in Queen's University Belfast Research Portal

\section{General rights}

Copyright for the publications made accessible via the Queen's University Belfast Research Portal is retained by the author(s) and / or other copyright owners and it is a condition of accessing these publications that users recognise and abide by the legal requirements associated with these rights.

Take down policy

The Research Portal is Queen's institutional repository that provides access to Queen's research output. Every effort has been made to ensure that content in the Research Portal does not infringe any person's rights, or applicable UK laws. If you discover content in the Research Portal that you believe breaches copyright or violates any law, please contact openaccess@qub.ac.uk. 


\title{
CHEMOSPHERE
}

\section{Soil Cd availability to Indian mustard and environmental risk following EDTA addition to Cd-contaminated soil}

\author{
X.J. Jiang ${ }^{\text {a }}$, Y.M. Luo ${ }^{\text {a,*, Q.G. Zhao }}{ }^{\text {a }}$, A.J.M. Baker ${ }^{\text {, }}$, \\ P. Christie ${ }^{\mathrm{c}}$, M.H. Wong \\ ${ }^{a}$ Institute of Soil Science, Chinese Academy of Sciences, P.O. Box 821, Nanjing 210008, China \\ ${ }^{\mathrm{b}}$ School of Botany, The University of Melbourne, Parkville, VIC 3010, Australia \\ ' Queen's University Belfast, Newforge Lane, Belfast BT9 5PX, UK \\ ${ }^{\mathrm{d}}$ Department of Biology, Hong Kong Baptist University, Kowloon Tong, Kowloon, Hong Kong, PR China
}

\begin{abstract}
A pot experiment was conducted to investigate the influence of EDTA on the extractability of Cd in the soil and uptake of Cd by Indian mustard (Brassica juncea). Twenty levels of soil Cd concentration ranging from 10 to 200 $\mathrm{mg} \mathrm{kg}{ }^{-1}$ were produced by spiking aliquots of a clay loam paddy soil with $\mathrm{Cd}\left(\mathrm{NO}_{3}\right)_{2}$. One week before the plants were

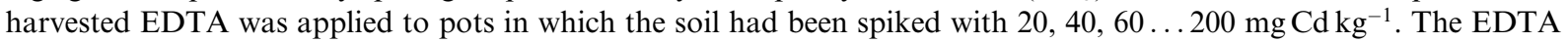
was added at the rate calculated to complex with all of the Cd added at the $200 \mathrm{mg} \mathrm{kg}^{-1}$ level. Control pots spiked with $10,30,50 \ldots 190 \mathrm{mg} \mathrm{Cd} \mathrm{kg}^{-1}$ received no EDTA. The plants were harvested after 42 days' growth. Soil water- and $\mathrm{NH}_{4} \mathrm{NO}_{3}$-extractable $\mathrm{Cd}$ fractions increased rapidly following EDTA application. Root Cd concentrations decreased after EDTA application, but shoot concentrations increased when the soil Cd levels were $>130 \mathrm{mg} \mathrm{kg}^{-1}$ and Cd toxicity symptoms were observed. The increases in soil solution Cd induced by EDTA did not increase plant total Cd uptake but appeared to stimulate the translocation of the metal from roots to shoots when the plants appeared to be under $\mathrm{Cd}$ toxicity stress. The results are discussed in relation to the possible mechanisms by which EDTA may change the solubility and bioavailability of $\mathrm{Cd}$ in the soil and the potential for plant uptake and environmental risk due to leaching losses to groundwater.
\end{abstract}

(c) 2002 Elsevier Science Ltd. All rights reserved.

Keywords: Chelate; Phytoextraction; Soil solution; Trace metal; Translocation

\section{Introduction}

Phytoextraction, the use of plants to remove toxic metals from soils, is emerging as a potentially costeffective and environmentally sound remediation technique for metal-contaminated soils (McGrath, 1998), and there are two general strategies currently under investigation. The first is the use of hyperaccumulator plant species with exceptionally high metal-accumulating capacities but with relatively low yields ('natural

\footnotetext{
${ }^{*}$ Corresponding author. Tel.: +86-25-3228-236; fax: +86-253353-590.

E-mail address: ymluo@mail.issas.ac.cn (Y.M. Luo).
}

phytoextraction'). The second is the use of high yielding crop plants that can take up relatively large amounts of metals only when the mobility of the metals in the soil is elevated by the application of chemical agents ('chemically assisted phytoextraction'). Various chelates, including EDTA, have been used to increase the solubility of soil metals and have been reported to have significant effects on the phytoextraction of several heavy metals, especially $\mathrm{Pb}$ (Blaylock et al., 1997; Huang et al., 1997). Wallace et al. (1974) first suggested that the metalEDTA complexes formed in the soil could increase metal solubility and promote diffusion, and thus increase the potential for plant uptake. However, Halvorson and Lindsay (1977) found that chelates in the soil lowered metal toxicity and uptake. EDTA was also reported to 
be a useful amendment for lowering the toxicity of Mn (Denduluri, 1994a) and Pb (Denduluri, 1993, 1994b) to okra grown in a soil irrigated with sewage. Moreover, application of EDTA to the soil has been observed to lead to decreases in the uptake of Cd (Wolterbeek et al., 1988), Ni (Albasel and Cottenie, 1985) and Zn (Laurie et al., 1991) by plants.

Some of the apparent contradictions in the results of studies reported by different laboratories may be attributable to phytotoxicity of metals or EDTA. In this paper we report a pot experiment in which the effects of EDTA applied to a clay loam soil on $\mathrm{Cd}$ uptake by Indian mustard were studied. Twenty levels of soil $\mathrm{Cd}$ ranging from 10 to $200 \mathrm{mg} \mathrm{kg}^{-1}$ in $10-\mathrm{mg} \mathrm{kg}^{-1}$ increments were produced by adding $\mathrm{Cd}\left(\mathrm{NO}_{3}\right)_{2}$ to triplicate aliquots of the soil prior to plant growth. EDTA was applied to the soil one week before the plants were harvested, and control pots were established with no EDTA treatment. The higher Cd levels were included to induce $\mathrm{Cd}$ phytotoxicity in an attempt to elucidate the potential role of metal toxicity in plant $\mathrm{Cd}$ uptake in EDTA-amended soil.

\section{Materials and methods}

A clay loam paddy soil $(0-20 \mathrm{~cm})$ developed from lacustrine sediments was air-dried and ground to pass through a 2-mm nylon mesh sieve. Selected properties of the soil were as follows: $\mathrm{pH}\left(\mathrm{H}_{2} \mathrm{O}\right) 7.40$; organic matter $36.3 \mathrm{~g} \mathrm{~kg}^{-1}$; total $\mathrm{N} 2.25 \mathrm{~g} \mathrm{~kg}^{-1}$; total $\mathrm{P} 0.75 \mathrm{~g} \mathrm{~kg}^{-1}$; total $\mathrm{K} 17.4 \mathrm{~g} \mathrm{~kg}^{-1}$; total $\mathrm{Cd} 0.07 \mathrm{mg} \mathrm{kg}^{-1}$; free $\mathrm{Fe}_{2} \mathrm{O}_{3} 16.2$ $\mathrm{g} \mathrm{kg}^{-1}$; CEC $216 \mathrm{mmol} \mathrm{kg}^{-1}$. Soil subsamples were mixed with appropriate amounts of analytical reagent (AR) grade solid $\mathrm{Cd}\left(\mathrm{NO}_{3}\right)_{2}$ in order to add 10-200 $\mathrm{mg} \mathrm{Cd} \mathrm{kg} \mathrm{of}^{-1}$ soil (oven dry basis) in increments of 10 $\mathrm{mg} \mathrm{kg}^{-1}$, resulting in 20 soil $\mathrm{Cd}$ levels. Basal fertiliser was applied as $\mathrm{AR} \mathrm{KH}_{2} \mathrm{PO}_{4}$ to give $80 \mathrm{mgP}$ and 100 $\mathrm{mg} \mathrm{K} \mathrm{kg}{ }^{-1}$. Nitrogen was added as $\mathrm{NH}_{4} \mathrm{NO}_{3}$ to give the same $\mathrm{N}$ application rate to each treatment. The metal and fertiliser salts were thoroughly mixed with the soil. The mixture was then adjusted with distilled water to $60 \%$ of water holding capacity (WHC) and maintained at this moisture content for two days. The moistened subsamples were mixed thoroughly again and aliquots (equivalent to $350 \mathrm{~g}$ oven dry basis and containing $\sim 80 \mathrm{~g}$ of added water to reach $60 \%$ WHC) were transferred to acid-washed plastic pots and sown with seeds of Brassica juncea. After emergence, the seedlings were thinned to two per pot. There were three replicates of each treatment in a randomised block design. During the period of plant growth, all pots were weighed and adjusted daily to $60 \%$ WHC with distilled water. The plants were grown in a glasshouse for 42 days. One week before harvest, half of the $\mathrm{Cd}$ treatments $(20,40,60 \ldots$ $200 \mathrm{mg} \mathrm{Cd} \mathrm{kg}^{-1}$ ) were supplemented with $25 \mathrm{ml} 1.78$ mmoll $1^{-1}$ EDTA from the base of each pot. The application rate of EDTA used was calculated to be the stoichiometrically exact amount to complex with the $\mathrm{Cd}$ in the soil spiked with $200 \mathrm{mg} \mathrm{Cd} \mathrm{kg}^{-1}$, the same as was used in previously reported experiments (Luo et al., 1999; Wu et al., 2000). Alternate Cd treatments (10, 30, $50 \ldots 190 \mathrm{mg} \mathrm{Cd} \mathrm{kg}^{-1}$ ) were controls that received no EDTA. At harvest, the shoots were cut at the shootroot junction. Both shoots and roots were washed with distilled water and dried at $70{ }^{\circ} \mathrm{C}$ for $48 \mathrm{~h}$. The ovendried samples were weighed, ground and subsamples digested with $\mathrm{HNO}_{3}-\mathrm{HClO}_{4}$. The resulting solutions were analysed for $\mathrm{Cd}$ concentration by atomic absorption spectrophotometry with a graphite furnace (GFAAS) using a model Z-8200 spectrophotometer.

Soil samples were collected from the pots after harvest and analysed for: (1) water-extractable $\mathrm{Cd}$ : distilled water was added to give a 1:1 (w/v) soil:solution ratio, the suspension was shaken at $120 \mathrm{rpm}$ for $1 \mathrm{~h}$ and centrifuged at $3500 \mathrm{rpm}$ for $10 \mathrm{~min}$, then the supernatant was filtered through Whatman No. 41 filter paper and passed through a $0.45 \mu \mathrm{m}$ membrane filter under negative pressure (1 bar); (2) $\mathrm{NH}_{4} \mathrm{NO}_{3}$-extractable $\mathrm{Cd}: 1 \mathrm{M}$ $\mathrm{NH}_{4} \mathrm{NO}_{3}$ was added to give a 1:2.5 (w/v) soil:solution ratio, the suspension was shaken at $120 \mathrm{rpm}$ for $1 \mathrm{~h}$ and the supernatant was filtered through Whatman No. 41 filter paper; and (3) EDTA-extractable Cd: EDTA (0.05 M, pH 7.0) was added to give a 1:5 (w/v) soil:solution ratio, the suspension was shaken at $120 \mathrm{rpm}$ for $1 \mathrm{~h}$ and the supernatant was filtered through Whatman No. 41 filter paper. All the filtrates were analysed for $\mathrm{Cd}$ by GFAAS. The results are presented as the mean values of three replicates of each treatment together with the standard errors of the means (SEM).

\section{Results}

\subsection{Influence of EDTA on plant growth}

Fig. 1 shows the influence of EDTA treatment one week before harvest on shoot and root dry matter yields of plants grown in pots for 42 days. Both root and shoot yields were lower in EDTA treated pots with soil $\mathrm{Cd}$ concentrations of up to about $100 \mathrm{mg} \mathrm{kg}^{-1}$, and the effect was more pronounced on the shoots. At soil $\mathrm{Cd}$ concentrations above about $100 \mathrm{mg} \mathrm{kg}^{-1}$ there were no differences between yields of EDTA treated and control plants, and root and shoot yields of all plants declined with increasing soil $\mathrm{Cd}$ concentration.

\subsection{Influence of EDTA on soil Cd extractability}

Fig. 2 shows the influence of EDTA application on soil $\mathrm{Cd}$ extractability immediately after harvest. The 

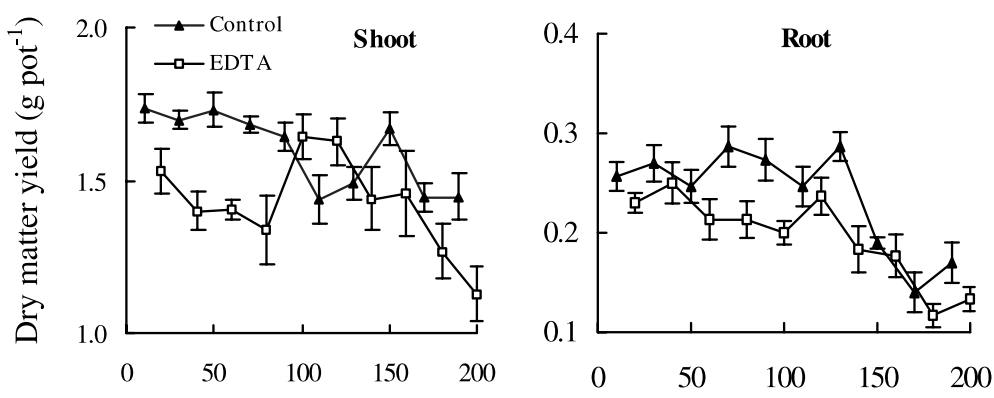

Cd added to soil $\left(\mathrm{mg} \mathrm{kg}^{-1}\right)$

Fig. 1. Influence of EDTA application to the soil one week before harvest on shoot and root yields of Indian mustard after 42 days' growth. Bars: SEM.
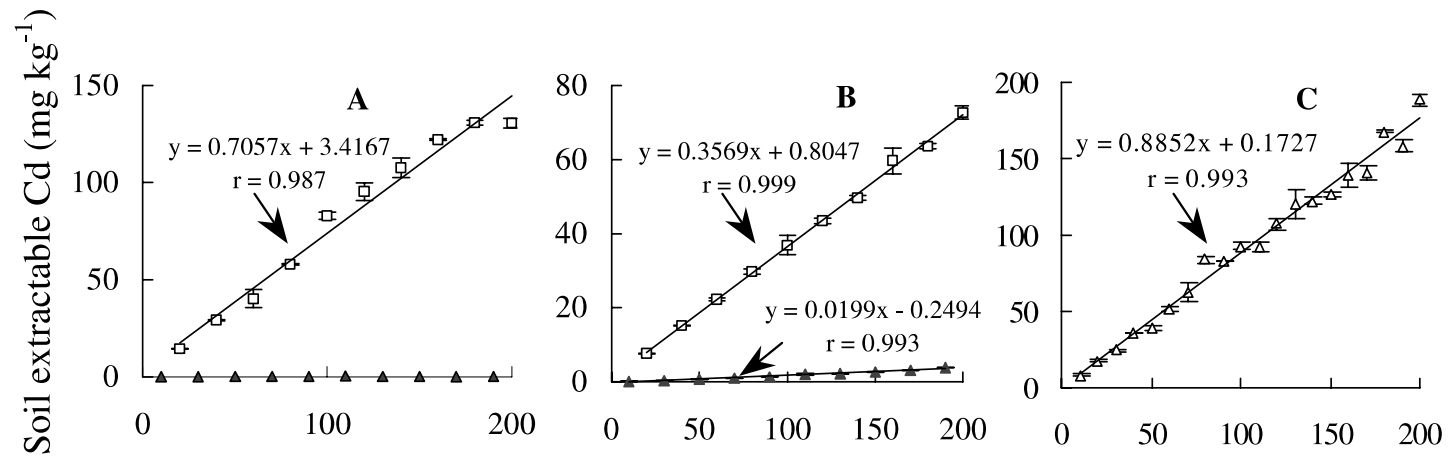

$\mathrm{Cd}$ added to soil $\left(\mathrm{mg} \mathrm{kg}^{-1}\right)$

Fig. 2. Influence of EDTA applied to the soil one week before harvest of Indian mustard on (A) $\mathrm{H}_{2} \mathrm{O}$-extractable; $(\mathrm{B}) \mathrm{NH}_{4} \mathrm{NO}_{3}$ extractable; and (C) EDTA-extractable Cd in the soil immediately after harvest. Symbols: (ム) control; ( $\square$ ) EDTA added. Bars: SEM.

concentration of water-extractable Cd increased sharply with increasing $\mathrm{Cd}$ application rate in the presence of EDTA but remained very low $\left(<0.2 \mathrm{mg} \mathrm{kg}^{-1}\right)$ in the unamended controls. The concentration of $\mathrm{NH}_{4} \mathrm{NO}_{3}$ extractable $\mathrm{Cd}$ also increased with increasing $\mathrm{Cd}$ application rate when EDTA was present and the controls showed a negligible increase at higher $\mathrm{Cd}$ application rates. In contrast, the increase in EDTA-extractable $\mathrm{Cd}$ with increasing $\mathrm{Cd}$ application rate occurred equally in both EDTA-treated and unamended control pots.

\subsection{Influence of EDTA on plant Cd concentration and uptake}

The effects of EDTA on plant shoot and root $\mathrm{Cd}$ concentrations are shown in Fig. 3. There were upward trends in $\mathrm{Cd}$ concentration in both shoots and roots with increasing soil $\mathrm{Cd}$ level. However, root $\mathrm{Cd}$ concentrations were consistently higher in the controls than in the EDTA-treated pots, but shoot concentrations were consistently lower in the controls. Shoot Cd concentra- tions increased dramatically in EDTA-treated pots between 150 and $200 \mathrm{mg} \mathrm{kg}^{-1} \mathrm{Cd}$ application rates, and the differences between these and the controls widened accordingly. Root and shoot $\mathrm{Cd}$ uptake values followed similar trends to the $\mathrm{Cd}$ concentrations in the plants (Fig. 4). Plant(root + shoot) Cd uptake by B. juncea was very similar in EDTA-treated and control soils with added $\mathrm{Cd}$ concentrations below about $150 \mathrm{mg} \mathrm{kg}^{-1}$. Above this concentration of soil Cd, EDTA-treated pots showed a sharp increase in total plant Cd uptake with increasing $\mathrm{Cd}$ application rate.

\section{Discussion}

Although differences were observed in root and shoot yields between EDTA-treated pots and controls, the differences were small and had little influence on the amounts of $\mathrm{Cd}$ taken up by the roots and shoots. However, the sharp decline in shoot yield of EDTAtreated plants at higher soil Cd levels together with the 


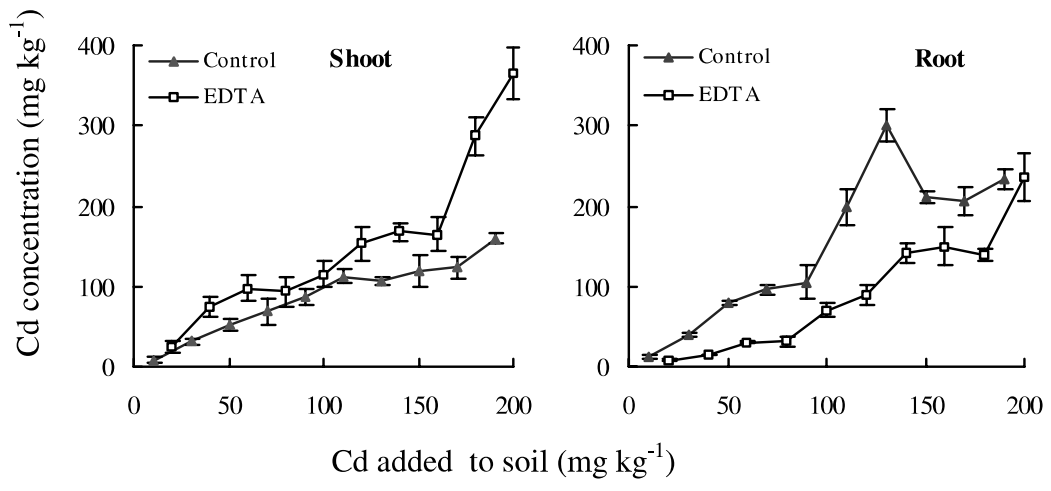

Fig. 3. Influence of EDTA applied to the soil one week before harvest on Cd concentrations in the roots and shoots of Indian mustard after growth for 42 days. Bars: SEM.
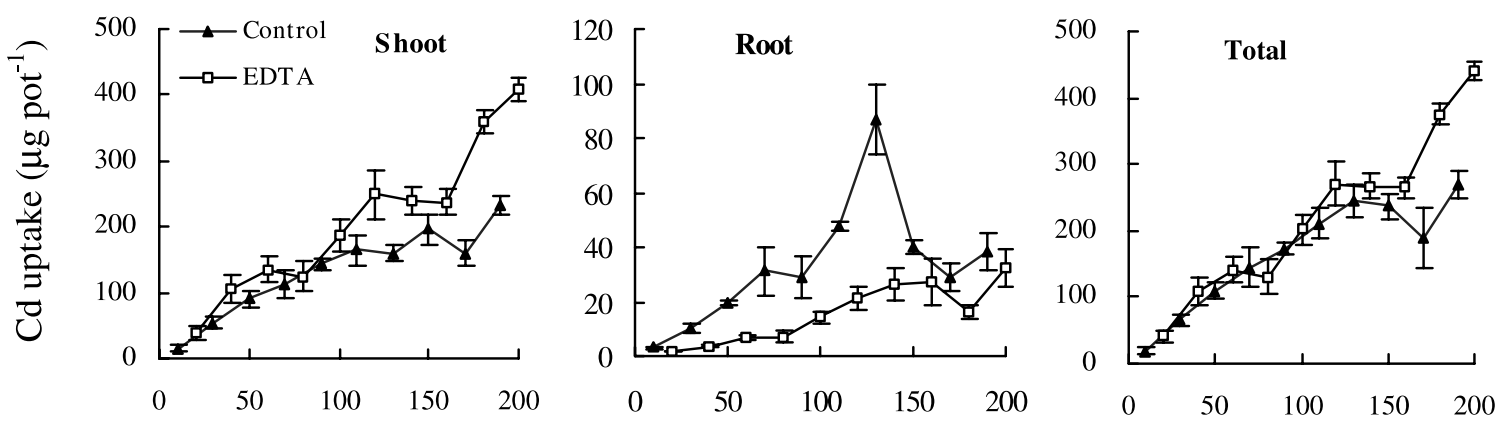

\section{Cd added to soil $\left(\mathrm{mg} \mathrm{kg}^{-1}\right)$}

Fig. 4. Influence of EDTA application to the soil one week before harvest on Cd uptake by shoots and roots of Indian mustard after 42 days' growth. Bars: SEM.

occurrence of visual symptoms indicates that Cd phytotoxicity occurred at the higher $\mathrm{Cd}$ application rates. The experiment could have been better designed for studying the effects of EDTA by adding the $\mathrm{Cd}$ in 20 $\mathrm{mg} \mathrm{kg}^{-1}$ increments to give six replicate pots, three for EDTA treatment and three controls, at each soil $\mathrm{Cd}$ level. The pairs of mean values could then have been compared by a statistical method such as the $t$-test or least significant difference. Nevertheless, the design adopted does allow comparison between trends in the data from the EDTA-treated and control pots.

The concentrations of both $\mathrm{H}_{2} \mathrm{O}-$ and $\mathrm{NH}_{4} \mathrm{NO}_{3}$ extractable Cd increased markedly in soil treated with EDTA (Fig. 2). However, plant shoot uptake and total Cd uptake did not increase accordingly, especially at low soil Cd concentrations (Fig. 4). The results indicate that $\mathrm{Cd}$ absorbed by $B$. juncea was not directly related to the $\mathrm{Cd}$ concentration in the soil solution. However, over the $\mathrm{Cd}$ concentration of $150 \mathrm{mg} \mathrm{kg}^{-1}$, EDTA addition resulted in a decrease in plant yield (Fig. 1) and an increase in shoot $\mathrm{Cd}$ concentration (Fig. 3). Salt et al.
(1997) reported that the roots of B. juncea had a greater capacity to accumulate $\mathrm{Cd}$, both intracellularly and adsorbed to the cell walls, than the shoots. This may explain, at least in part, the observed decrease in $\mathrm{Cd}$ accumulation in the treatments receiving EDTA. A contributing factor may have been desorption of $\mathrm{Cd}$ from cell walls by EDTA, and because of the large amount of $\mathrm{Cd}$ adsorbed to the cell walls the total amount of Cd taken up by the plants increased slightly, but did not correspond to the increased concentration of $\mathrm{Cd}$ in the soil solution. Thus, EDTA may have stripped non-specifically bound $\mathrm{Cd}$ from root cell walls, making it appear that the roots took up less Cd. In addition, added EDTA is also likely to have chelated soil-bound $\mathrm{Cd}$, and the EDTA-Cd complex would have gone into soil solution. EDTA-chelated Cd would then have been easily extracted by water from the soil samples, but would not have been taken up readily through root plasma membranes, particularly at low concentrations. When our soil water-extractable and $\mathrm{NH}_{4} \mathrm{NO}_{3}$-extractable $\mathrm{Cd}$ values were compared with shoot $\mathrm{Cd}$ uptake by 
linear correlation, they were both highly correlated with coefficients $(r)$ of $0.931 \quad(P<0.001)$ and 0.958 $(P<0.001)$ respectively. Thus, both extractants (and especially $\mathrm{NH}_{4} \mathrm{NO}_{3}$ ) were very good indicators of plantavailable $\mathrm{Cd}$.

The occurrence of some stimulation of Cd translocation from roots to shoots by EDTA when Cd levels were high enough to induce phytotoxicity cannot be discounted. One possible mechanism, suggested by Vassil et al. (1998) for $\mathrm{Pb}$, is that some of the soil-bound $\mathrm{Cd}$ was chelated by EDTA in the soil, as discussed above. Some of the soluble Cd-EDTA complex in the soil solution would then have been transported through the plant via the xylem to the shoots.

Indian mustard did not show any evidence of $\mathrm{Cd}$ hyperaccumulation in this experiment, with maximum shoot concentrations of $<400 \mathrm{mg} \mathrm{kg}^{-1}$, even with EDTA application to the soil. Furthermore, EDTA treatment did not substantially enhance shoot Cd uptake compared with unamended controls, although some enhancement of translocation from roots to shoots may have occurred at higher soil $\mathrm{Cd}$ levels at which $\mathrm{Cd}$ phytotoxicity (and lower shoot yields) occurred. Since soil water-extractable $\mathrm{Cd}$ increased at least 400 -fold following EDTA application, a more important concern may be alternative pathways for the soil $\mathrm{Cd}$ fraction rendered soluble by EDTA. In the field, dramatic increases in soil solution Cd could result in contamination of groundwater with consequent environmental impacts. Thus, the practical use of chelates for enhancement of metal removal in phytoremediation strategies may require careful site-specific evaluation to minimise the risk of serious secondary environmental contamination.

\section{Conclusions}

Indian mustard did not exhibit hyperaccumulation of $\mathrm{Cd}$ under the conditions of this experiment, although the maximum shoot uptake values obtained ( $>300 \mathrm{mg} \mathrm{kg}^{-1}$ ) could be useful in $\mathrm{Cd}$ removal by bioavailable element stripping in which the objective is to remove the bioavailable metal fraction. However, these uptake values were achieved at the higher soil $\mathrm{Cd}$ levels investigated, at which there was also evidence of $\mathrm{Cd}$ phytotoxicity. EDTA addition to the soil did not increase plant Cd uptake, but appeared to stimulate translocation of $\mathrm{Cd}$ from roots to shoots. Some of this apparent stimulation of translocation may have been due to non-specific stripping of Cd from root cell walls. EDTA application led to substantial increases in soluble $\mathrm{Cd}$ in the soil. Thus, EDTA treatment did not give substantially increased $\mathrm{Cd}$ removal by the plants but rendered a larger fraction soil Cd vulnerable to loss processes with consequent potential environmental risk.

\section{Acknowledgements}

We are grateful to the Natural Science Foundation of China (Nos. 49831070, 40125005 and 49871042), the Major State Basic Research and Development Program of the People's Republic of China (G1999011807) and Jiangsu Provincial Foundation for Young Scientists (BQ98050) for grant-aided support. We also thank Dr Jianwei Huang of Edenspace Systems Corporation, USA, for constructive discussion and suggestions.

\section{References}

Albasel, N., Cottenie, A., 1985. Heavy metals uptake from contaminated soils as affected by peat, lime, and chelates. Soil Soc. Am. J. 49 (2), 386-390.

Blaylock, M.J., Salt, D.E., Dushenkov, S., Zakharova, O., Gussman, C., Kapulnik, Y., Ensley, B.D., Raskin, I., 1997. Enhanced accumulation of $\mathrm{Pb}$ in Indian mustard by soilapplied chelating agents. Environ. Sci. Technol. 31 (3), 860865.

Denduluri, S., 1993. Reduction of lead accumulation by ethylenediamine tetraacetic acid and nitrilo triacetic acid in okra (Abelmoschus esculentus L.) grown in sewageirrigated soil. Bull. Environ. Contam. Toxicol. 51 (1), 4045.

Denduluri, S., 1994a. Reduction of manganese accumulation by ethylenediamine tetraacetic acid and nitrilo triacetic acid in okra (Abelmoschus esculentus L.) grown in sewage-irrigated soil. Bull. Environ. Contam. Toxicol. 52 (3), 438-444.

Denduluri, S., 1994b. Ameliorative effects of ethylenediamine tetraacetic acid and nitrilo triacetic acid on lead toxicity in okra (Abelmoschus esculentus L.) grown in sewageirrigated soil. Bull. Environ. Contam. Toxicol. 52 (4), 516522.

Halvorson, A.D., Lindsay, W.L., 1977. The critical $\mathrm{Zn}^{2+}$ concentration for corn and the nonabsorption of chelated zinc. Soil Sci. Soc. Am. J. 41 (3), 531-534.

Huang, J.W., Chen, J.J., Berti, W.R., Cunningham, S.D., 1997. Phytoextraction of lead-contaminated soils: Role of synthetic chelates in lead phytoextraction. Environ. Sci. Technol. 31 (3), 800-805.

Laurie, S.H., Tancock, N.P., McGrath, S.P., Sanders, J.R., 1991. Influence of complexation on the uptake by plants of iron, manganese, copper and zinc. I. Effect of EDTA in a multi-metal and computer-simulation study. J. Exp. Bot. 42 (237), 509-513.

Luo, Y.M., Christie, P., Baker, A.J.M., 1999. Metal uptake by Thlaspi caerulescens J. \& C. Presl and metal solubility in a $\mathrm{Zn} / \mathrm{Cd}$ contaminated soil after addition of EDTA. In: Proc. 5th Int. Conf. on the Biogeochemistry of Trace Elements. Vienna, Austria, vol. 2, pp. 882-883.

McGrath, S.P., 1998. Phytoextraction for soil remediation. In: Brooks, R.R. (Ed.), Plants that Hyperaccumulate Heavy Metals. CAB International, Wallingford, UK, pp. 261288.

Salt, D.E., Pickering, I.J., Prince, R.C., Gleba, D., Dushenkov, S., Smith, R.D., Raskin, I., 1997. Metal accumulation by 
aquacultured seedlings of Indian mustard. Environ. Sci. Technol. 31 (6), 1636-1644.

Vassil, A.D., Kapulnik, Y., Raskin, I., Salt, D.E., 1998. The role of EDTA in lead transport and accumulation by Indian mustard. Plant Physiol. 117 (2), 447-453.

Wallace, A., Mueller, R.T., Cha, J.W., Alexander, G.V., 1974. Soil $\mathrm{pH}$, excess lime and chelating agent on micronutrients in soybeans and bush beans. Agron. J. 66 (5), 698-700.
Wolterbeek, H.T., Meer, A. van der, Bruin, M. de, 1988. The uptake and distribution of cadmium in tomato plants as affected by ethylenediamine tetraacetic acid and 2.4-dinitrophenol. Environ. Pollut. 55, 301-315.

Wu, L.H., Luo, Y.M., Lu, R.H., Wong, J.W.C., 2000. Chelateenhanced phytoremediation of $\mathrm{Cu}$-polluted Soil. II. Mobilisation of $\mathrm{Cu}$ in the rhizosphere. Soils 32, 68-70 (in Chinese). 